\title{
Absolute chronology of the Beaker phenomenon North of the Tagus estuary: demographic and social implications
}

\author{
Cronología absoluta del fenómeno campaniforme al Norte del estuario del Tajo: \\ implicaciones demográficas y sociales
}

\author{
João Luís Cardoso (*)
}

\begin{abstract}
The complexity of the Beaker phenomenon in the Tagus estuary does not fit well with the model of three successive groups (International, Palmela and Incised Groups). The above seems to result from the nature of the settlements rather than from its chronology, as all three groups are present during the second half of the $3^{\text {rd }}$ millennium BC. Therefore while artefacts of the International Group predominate in the fortified sites, the Incised Group appears almost exclusively in open sites. The Palmela Group seems of minor importance, at least in the north region of the Tagus River estuary. The remarkable antiquity of Beaker pottery found in the FM hut at Leceia (which dates from the $2^{\text {nd }}$ quarter of the $3^{\text {rd }}$ millennium $\mathrm{BC}$, re-confirmed by AMS dating) has parallels both in the North and South of Portugal, as well as in Spain. Thus we conclude that in the Lower Estremadura (one of the most important regions in Europe for the discussion of the origin and diffusion of Beaker "phenomenon"), the Beaker social formation with its own distinct cultural characteristics, coexisted with local Chalcolithic cultures, although never merged with them.
\end{abstract}

\section{RESUMEN}

La complejidad del fenómeno campaniforme en el estuario del Tajo no encaja bien con el modelo de los tres Grupos sucesivos Internacional, Palmela e Inciso. Dicho modelo parece resultar de la naturaleza de los asentamientos más que de su cronología, ya que los tres grupos están presentes durante la segunda mitad del III milenio a.C. Mientras los artefactos del Grupo Internacional predominan en los sitios fortificados, los del Grupo Inciso se encuentran casi en exclusiva en yacimientos

(*) Open University (Universidade Aberta), Lisbon and Center for Archaeological Studies of Oeiras Municipality Council (CEACO/CMO). Rua Silva Porto 16. 2825-834 Funchalinho. Trafaria, Portugal. E-mail: cardoso18@netvisao.pt

Recibido 27-IX-2012; aceptado 8-I-2013. al aire libre. El Grupo Palmela parece menos importante, al menos en la región septentrional del estuario del Tajo. La notable antigüedad de la cerámica campaniforme hallada en la cabaña FM de Leceia (segundo cuarto del III milenio a. C., confirmada por datación AMS) tiene paralelos al Norte y Sur de Portugal, así como en España. En consecuencia, concluimos que en la Baja Estremadura (una de las regiones más importantes de Europa para discutir el origen y difusión del "fenómeno" campaniforme), la formación social campaniforme con sus características culturales distintivas coexistió con las culturas calcoliticas locales sin mezclarse nunca con ellas.

Key words: Beaker pottery; Portugal; Absolute chronology; Demography; Social organization.

Palabras clave: Campaniforme; Portugal; Cronología absoluta; Demografia; Organización social.

\section{INTRODUCTION}

Research about Beaker "phenomenon" in Portuguese Estremadura underwent a significant advance with the pioneering work of J. Soares and C. Tavares da Silva (1974/1977). This contribution provided a model for its internal phasing which is still accepted by the generality of archaeologists. In fact the model's coherence derives from the archaeological record itself, and despite not being sustained by new radiocarbon dating it has remained until now broadly operative.

The model postulated that Beaker sequence began with vessels decorated by a stippling technique, involving a predominance of maritime AOO Beakers decorated with alternately-filled horizontal bands ("herringbone" pattern), associated to other vessels such as shoulder pots. Found 
at topographically elevated sites, this was the material support for the so-called "International Group" - which was present during Full Chalcolithic occupation of those sites, coexisting with "acacia leaf" a regional decorative pattern. This was followed by a period of miscegenation with pre-existing ceramic decorative patterns and techniques, when the stippling technique was applied to vessels with a very elaborated and decorated rim (Palmela bowls) and other pre-existing vessels. It is well represented around the Sado River estuary and is known as the Palmela Group. Finally, according to this theory, the end of the Beaker cycle was marked by the predominance of incised decorations (Incised Group). This group is particularly found in small domestic sites such as family-based farms or small farming communities. According to this traditional model the Beaker cycle as a whole corresponded to the last stage of the Chalcolithic in Estremadura, which preceded the Bronze Age. However, some authors argue that the later Beaker productions of the incised group were already Early Bronze Age. This brought new ways of land occupation during which the fortified settlements, where population had previously been concentrated, gave way to a dispersed demographic model, more conducive to agriculture and animal-rearing in the fertile fields of the region.

Although very robust from the conceptual point of view the mentioned model began to be challenged by the publication of the first radiocarbon dates from enclosed Beaker contexts in Estremadura, obtained at the prehistoric settlement of Leceia. This showed a clearly-defined stratigraphic contexts, and supported the evidence previously obtained at the prehistoric settlement of Zambujal regarding the antiquity of Beaker vessels (Kunst 1987, 1996, 2010; Kunst and Lütz 2008, 2010/2011). In fact, the absolute chronology obtained for one of the huts found outside the walls of Leceia (hut FM), dating from the $2^{\text {nd }}$ quarter of the $3^{\text {rd }}$ millennium BC (when Beaker culture was emerging in Portuguese Estremadura), challenged the three-part sequence of the Chalcolithic in that region, as it preceded the cultural phase traditionally designed by Full Chalcolithic (Cardoso and Soares 1990/1992).

Another consequence of the discovery of a hut exclusively consisting of Beaker remains was the possibility of attributing the Beaker "phenomenon" to an independent populational dynamic of that associated to the genesis and development of Chalcolithic in Estremadura. That is to say, there appeared to be two distinct but contemporaneous social realities, coexisting in the same space. Thus, assuming that different material cultures correspond to distinct communities, we were once more in a position to reignite the debate about the status of the Beaker populations that occupied the Estremadura region, based on new archaeological data (Fig. 1). In fact thanks to the research carried out in the last decade we know that Beaker "phenomenon" coexisted for several hundred years in Lower Estremadura with other material cultures. For example, the fortified Chalcolithic settlement of Outeiro Redondo (Sesimbra) was occupied throughout the second half of the $3^{\text {rd }}$ millennium BC (Cardoso et al. 2010/2011) but had no effective Beaker presence (Cardoso 2010), despite being located in one of the greatest incidence areas of Beaker sites in Iberian Peninsula.

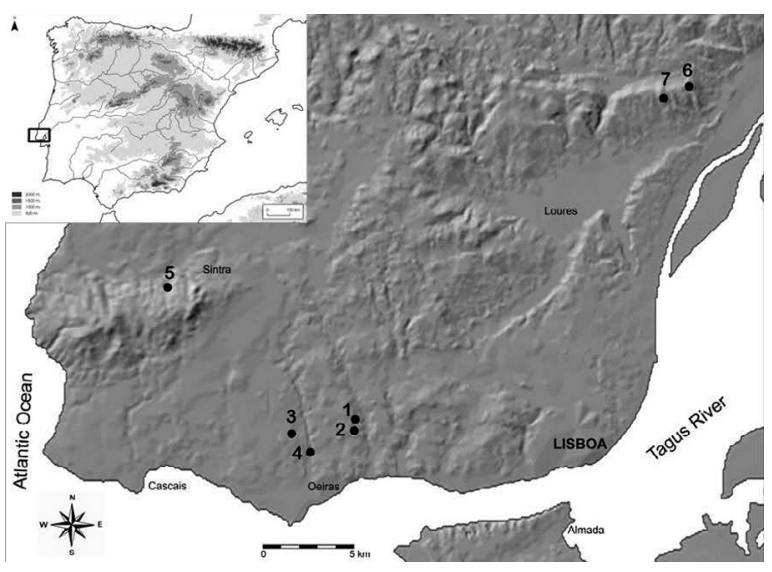

Fig. 1. Settlements of Lower Estremadura region discussed in this work: 1-Leceia; 2-Monte do Castelo; 3 Freiria; 4-Ponte da Laje; 5-Penha Verde; 6-Moita da Ladra; 7-Cave of Vendelhados Ruivos.

The lack of operative value for the Beaker sequence described above is also demonstrated. In the case of the hut FM at Leceia vessels characteristic of International, Palmela and Incised Groups were found together in a structure that would necessarily have been short-lived, emphasising their contemporaneousness. The logical conclusion is that these groups have no chronological significance (Cardoso 1997/1998).

Thus this work aims to present some considerations about the chronology and socio-cultural 
characteristics of the Beaker "phenomenon" in Lower Estremadura, one of the most rich and important regions in Europe, based on new excavations and absolute chronology, together with a revision of some already studied collections. The ideas here presented are by no means definitive and they should be viewed as working hypothesis on how we might interpret the archaeographic data that is currently available. The claims made are, of course, subject to further discussion and confirmation with new data.

\section{DATA AND CONTEXTS: STRATIGRAPHIC AND TYPOLOGICAL ASPECTS, AND THE RESPECTIVE ABSOLUTE CHRONOLOGY}

The Beaker materials that were studied come from very different contexts and were evaluated regarding the nature of the sites and the period when the archaeological interventions took place: Leceia, Monte do Castelo, Freiria, Cave of Ponte da Lage, Penha Verde, Moita da Ladra, Cave of Verdelha dos Ruivos. Information from published work as well as the recovery of unpublished excavation records has enabled us to overcome many legitimate doubts raised in the absence of such documents. It should be pointed out that all published materials and their respective contexts were directly observed, whether or not they resulted from archaeological works directed by the author.

1. Leceia: Excavations undertaken at the important fortified Chalcolithic settlement (Cardoso 2000a, 2008) have yielded the following conclusions, regarding the Beaker presence (Cardoso 1997/1998, 2000b, 2001, 2004, 2005), inside and outside the fortification.

Around 2600/2500 BC the fortified settlement was already in sharp decline as indicated by the quality of the architecture and building work. During the period, corresponding to the transition between Early Chalcolithic, represented by fluted ceramic vessels, and Full Chalcolithic, its occupants received the influx of maritime vessels. These materials were stratigraphically associated with other ceramic vessels decorated with "acacia leaf" pattern, a well-known regional style (Cardoso 2007). This was indicative that during a short period these two traditions coexisted. If we accept that different archaeological materials re- flect different social and cultural realities, then the stratigraphically-supported evidence from Leceia reopens the old question concerning the existence of a Beaker archaeological culture related with a group responsible for the dissemination of Beaker artefacts. At Rotura, Setúbal, a similar context was detected (Ferreira and Silva 1970; Gonçalves 1971; Silva 1971).

Dominated by maritime vessels, Beaker productions were found in the upper part of Layer 2, immediately covered by Layer 1 (the surface layer). Layer 2 contained a mixture of the already mentioned regional decorated productions, and Beaker pieces (Tab. 1), concentrated on the highest part of the archaeological site (Fig. 2). There were clearly more fragments with stippled decoration (34 fragments) than with incised decoration (5 fragments) (Fig. 3). Dating obtained for Layer 2 placed its formation during the second half of the $3^{\text {rd }}$ millennium BC with several dates in the last quarter (Cardoso 1997/1998).

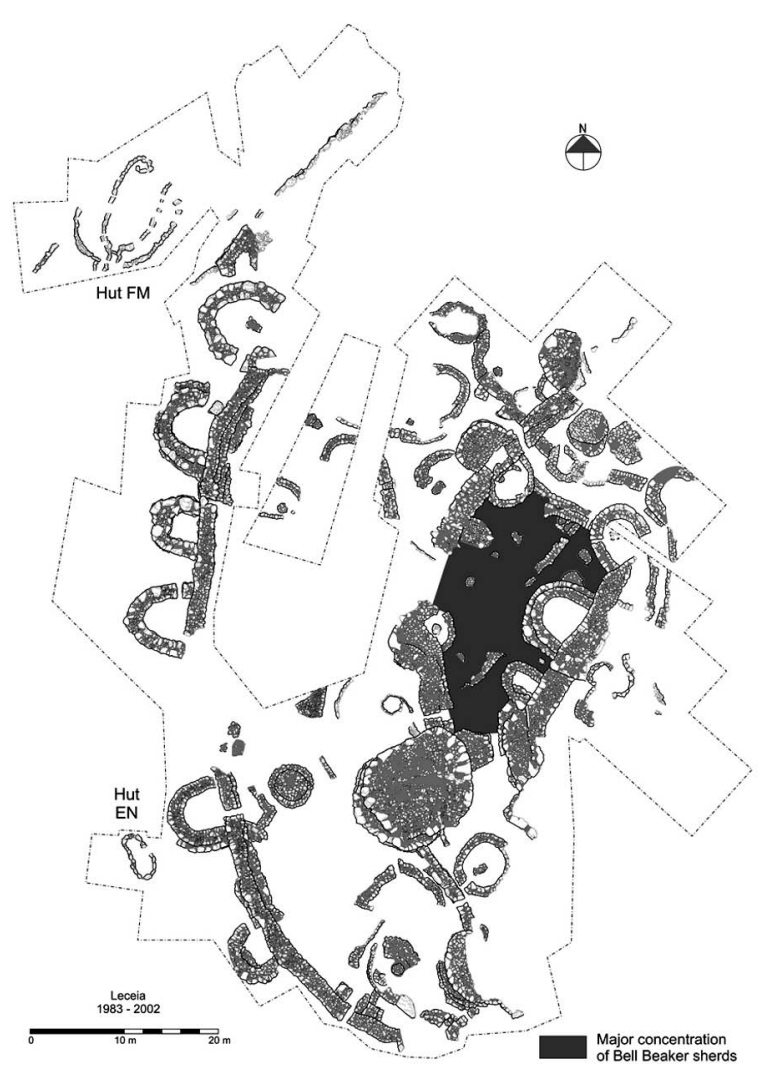

Fig. 2. Leceia. Plan of the fortified settlement, with the location of the two Bell Beaker huts identified outside the walls. 


\begin{tabular}{|c|c|c|c|c|c|c|c|c|c|c|}
\hline & DECORATION and SHAPE & $\begin{array}{l}\text { Leceia } \\
\text { Fortifi- } \\
\text { cation }\end{array}$ & $\begin{array}{c}\text { Leceia } \\
\text { FM } \\
\text { HUT }\end{array}$ & $\begin{array}{c}\text { Leceia } \\
\text { EN HUT }\end{array}$ & $\begin{array}{c}\text { Monte } \\
\text { do } \\
\text { Castelo }\end{array}$ & Freiria & $\begin{array}{c}\text { Ponte da } \\
\text { Lage }\end{array}$ & $\begin{array}{c}\text { Moita } \\
\text { da } \\
\text { Ladra }\end{array}$ & $\begin{array}{c}\text { Verdelha } \\
\text { dos } \\
\text { Ruivos }\end{array}$ & $\begin{array}{l}\text { Penha } \\
\text { Verde }\end{array}$ \\
\hline $\mathrm{S}$ & $\begin{array}{c}\text { Maritime Beaker vessels with stippled } \\
\text { decoration }\end{array}$ & 22 & 13 & & & 8 & & 31 & 1 & 41 \\
\hline $\mathrm{S}$ & $\begin{array}{l}\text { Maritime Beaker vessels with stippled } \\
\text { linear decoration }\end{array}$ & 1 & 3 & & & & & 13 & 1 & 17 \\
\hline $\mathrm{S}$ & $\begin{array}{l}\text { Smooth-profile vessels with stippled } \\
\text { decoration }\end{array}$ & & 1 & & & & 1 & & & \\
\hline $\mathrm{S}$ & $\begin{array}{l}\text { Carinated vessels with stippled } \\
\text { decoration }\end{array}$ & 1 & 4 & 1 & & & & & & \\
\hline $\mathrm{S}$ & Shoulder vessels with stippled decoration & 1 & & & & & 2 & 16 & 1 & \\
\hline $\mathrm{S}$ & Large vessels with stippled decoration & 1 & 2 & 4 & & 5 & & & & \\
\hline $\mathrm{S}$ & Palmela cups with stippled decoration & & 7 & & & & 1 & & 1 & \\
\hline $\mathrm{S}$ & $\begin{array}{l}\text { Spherical vessels with stippled } \\
\text { decoration }\end{array}$ & & 1 & & & & & 1 & & \\
\hline $\mathrm{S}$ & $\begin{array}{l}\text { Calotte-shaped cups with stippled } \\
\text { decoration }\end{array}$ & 1 & 23 & 1 & & 8 & & 1 & 1 & 1 \\
\hline $\mathrm{S}$ & $\begin{array}{l}\text { Unclassifiable fragments with stippled } \\
\text { decoration }\end{array}$ & 7 & 15 & 1 & & 30 & & & & \\
\hline $\mathrm{S}$ & Geometric stippled vessels & & & & & & & 23 & & 36 \\
\hline I & $\begin{array}{c}\text { Maritime Beaker vessels with incised } \\
\text { decoration }\end{array}$ & 1 & 3 & & 5 & 21 & & & & 1 \\
\hline I & $\begin{array}{l}\text { Bell-beaker vessels with incised linear } \\
\text { decoration }\end{array}$ & 1 & & 1 & & 2 & & & & \\
\hline $\mathrm{I}$ & Carinated vessels with incised decoration & & 2 & 2 & 1 & & & & & \\
\hline I & Shoulder vessels with incised decoration & & 11 & & & & & 1 & & \\
\hline I & Large vessels with incised decoration & & 3 & 2 & & 98 & & & 1 & \\
\hline $\mathrm{I}$ & Palmela bowls with incised decoration & 1 & 7 & 4 & 2 & & 10 & & 6 & 8 \\
\hline I & $\begin{array}{l}\text { Calotte-shaped cups with incised } \\
\text { decoration }\end{array}$ & & 3 & & 8 & 3 & & & & 5 \\
\hline I & $\begin{array}{c}\text { Unclassifiable fragments with incised } \\
\text { decoration }\end{array}$ & 2 & 10 & 6 & & & & & 6 & 2 \\
\hline $\mathrm{I}$ & Large incised vessels & & & & 2 & & 7 & & & \\
\hline I & Incised vessels & & & & 3 & 136 & 5 & & & \\
\hline $\mathrm{I}$ & Incised bottles & & & & 2 & & & & & \\
\hline I & $\begin{array}{l}\text { Smooth-profile vessels with incised } \\
\text { decoration }\end{array}$ & & & & & & & & 2 & \\
\hline I & $\begin{array}{l}\text { Calotte-shaped cups with incised } \\
\text { decoration }\end{array}$ & & & & & 60 & 1 & & & \\
\hline I & Incised Palmela cups & & & & & 34 & & & & \\
\hline I & Incised spherical vessels & & & & & & 1 & & & \\
\hline $\mathrm{I}$ & Geometric incised vessels & & & & & & & & & 15 \\
\hline $\mathrm{I}$ & Incised spherical vessels & & & & & & 1 & & & \\
\hline I & Geometric incised vessels & & & & & & & & & 15 \\
\hline
\end{tabular}

Tab. 1. Decoration and shape of Beaker vessels from the settlements of Lower Estremadura region (Portugal). S: stippled; I: incised. 


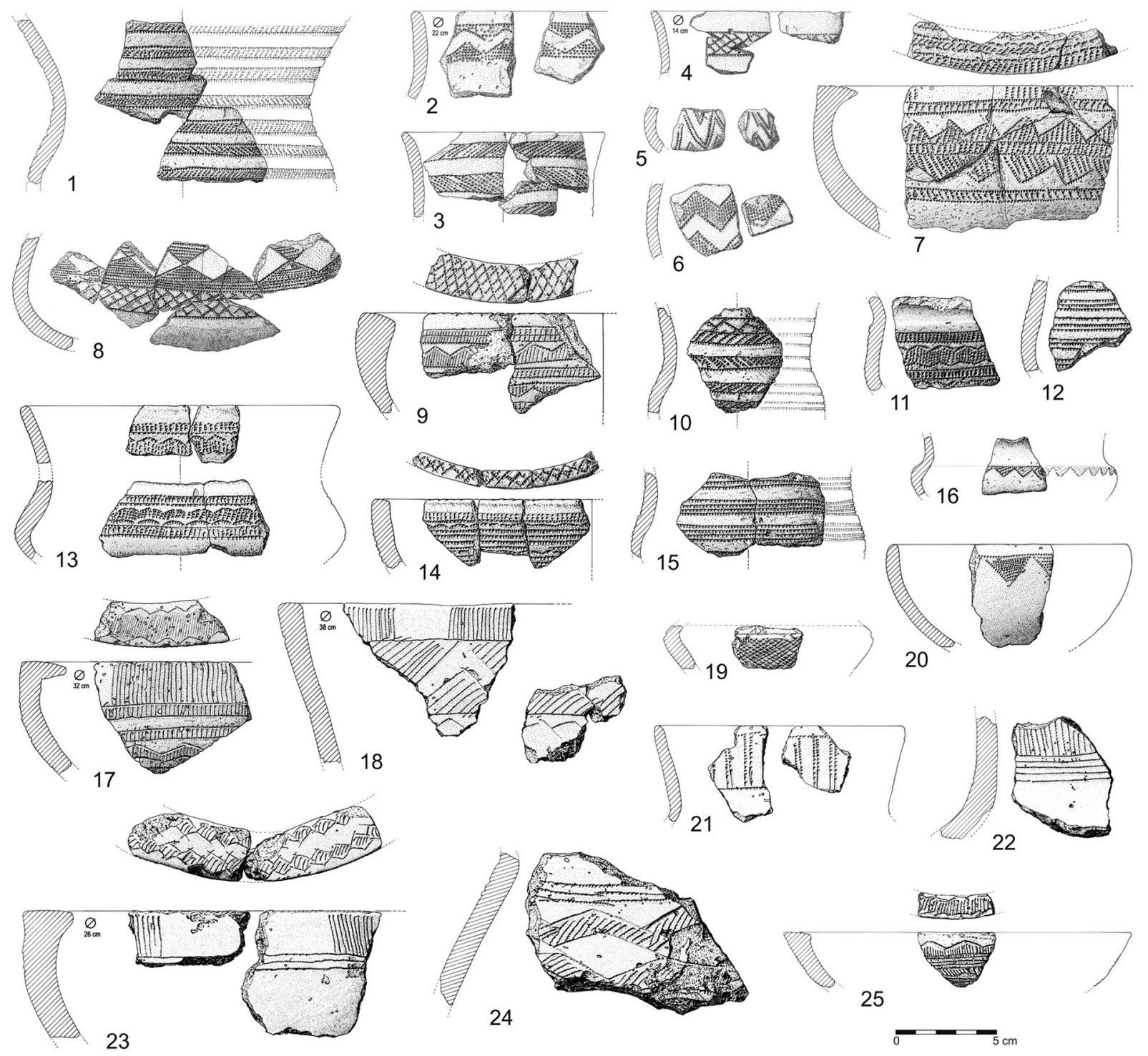

Fig. 3. Leceia. Beaker ceramics from the space inside the walls (n. $\left.{ }^{\circ} 1-8\right)$; from Hut FM (n. $\left.{ }^{\circ} 9-18\right)$ and Hut EN (n. ${ }^{\circ} 19-$ 25). Draws: B. L. Ferreira (CEACO/CMO).

Two huts with ellipsoid ground plans have been identified outside the fortified area. The ceramic vessels found in both huts are exclusively Bell Beaker types, as there are no decorated fragments belonging to local styles. This seems to assure the material culture of the respective occupants.

FM hut would have housed a small community, perhaps a family group. It consisted of a large hut formed by two lines of large blocks, with an ellipsoidal ground plan (Fig. 2). Since this residential unit was built on a regular platform at the highest part of the archaeological site, it is unlikely that the materials were transported there from other parts of the site by natural agents. This conclusion is confirmed by the total absence of rolling and erosion on the surfaces of the Beaker ceramic fragments. It is also unlikely that they belonged to different Chalcolithic periods because there is a total absence of earlier ceramic materials such as fragments bearing the well-known fluted decoration, attributa- 
ble to Early Chalcolithic, or the acacia-leaf pattern, mentioned above, and attributed to Full Chalcolithic. The structure seats directly on a Late Neolithic layer, which has been radiocarbon-dated to the second half of the $4^{\text {th }}$ millennium BC (Cardoso and Soares 1996). Hence, there is a gap of several hundred years with regard to the dates of the bone remains now published. Given the results obtained it cannot belong to any context other than that of the Beaker hut in question, where they were collected. Thus we can conclude that the 108 Beaker fragments gathered inside the hut correspond to waste resulting from its occupation, which was certainly limited in time. The pottery is very fragmented and comes from many different vessels. However this is to be expected from the excavation of a large housing unit like this one $(12 \mathrm{~m} \times 5 \mathrm{~m}$ at its largest points, Cardoso 1997/1998) and also explains the very incomplete state of most of the vessels. There is no evidence of any structural remodelling work associated to different periods. The decorated ceramic remains collected inside this dwelling unit consists exclusively of Beaker materials. This seems to indicate that this community used a much greater range of Beaker vessels in their daily lives than those living inside the fortification (Fig. 3). We can see the predominance of the stippled technique (69 fragments) compared to the incised (39 fragments), although the difference is less accentuated than inside the fortress.

When these results were first published (Cardoso 1997/1998) some questions were raised: firstly, the heterogeneity of the Beaker materials could suggest that there was mixing of those fragments at different times; secondly, the early chronology obtained by dating (Sac-1317: 4220 \pm 50 BP: $2920-2630$ cal BC, 2 б) seemed too early. In order to clarify this issue, two samples of bones were selected from the Beaker context (i.e., stratigraphically associated with the occupation of the hut), which were then dated by AMS (Beta-260297: $4140 \pm 40$ BP and Beta-260299: $4100 \pm 40 \mathrm{BP})$. These new results confirmed the value obtained earlier by the conventional method, which used around $150 \mathrm{~g}$ of bones, corresponding to some 15 fragments. The results of the three dates obtained are consistent with each other and prove that the chronology of the Beaker FM hut, and consequently its content dated from the $2^{\text {nd }}$ quarter of the $3^{\text {rd }}$ millennium $\mathrm{BC}$, prior to the chronology of the Beaker presence inside the fortification.

EN hut also located outside the walled enclosure (Fig. 2), like the FM hut, has an ellipsoidal ground plan defined by limestone blocks, delimiting a superstructure made of perishable materials. However it is smaller than the other, only 4 $\mathrm{m}$ long and $2 \mathrm{~m}$ wide at the largest point. The base of the structure was partly sealed by rubble from the fortification walls that stretched for some 10 meters. Compared with the set from the larger Beaker hut (Tab. 1), the formal and decorative repertoire is less extensive (Fig. 3). This might have been due to the smaller size hut. The group differs even more significantly from that collected inside the walled area. Not only because of the clear predominance of the incised technique, but also because of the total absence of certain items, such as maritime vessels. There is no mixing of materials (pottery or bone) in this case either. Pottery fragments have fresh surfaces, probably because they were rapidly covered by rubble from the falling walls, which would have preserved the archaeological layer inside the hut.

Dating of an osteological collection from the terrestrial biosphere collected inside the structure (ICEN-1241: $3950 \pm 90 \mathrm{BP}$ ) indicates that it does not differ from the chronology corresponding to the Beaker presence inside the fortification. To check that there had been no mixing of materials from different periods two AMS dates (bones from the terrestrial biosphere: Beta-260295: 3840 $\pm 40 \mathrm{BP}$ and Beta-260296: $3980 \pm 40 \mathrm{BP}$ were obtained) (Tab. 2). This seems to confirm the $3^{\text {rd }}$ quarter of the $3^{\text {rd }}$ millennium $\mathrm{BC}$ as the most probably chronology for this hut. These results confirms that the small Beaker group housed in the EN hut was contemporaneous with the community inside the walled area.

2. Monte do Castelo: A small cluster of exclusively Beaker vessels was collected at the surface within a circumscribed area after a recent tillage of the soil. This finding was on a gentle slope on the right bank of the Barcarena River, about $700 \mathrm{~m}$ south of Leceia (Cardoso et al. 1996). This evidence suggests an isolated dwelling, similar to others found in the same region, such as that recently published from Leião (Cardoso 2010/2011a). We can verify that the whole group is made up exclusively of incised Beaker ceramics (Fig. 4), and even the maritime vessels are represented by 5 fragments decorated with 


\begin{tabular}{|c|c|c|c|c|c|c|c|}
\hline & H 1 & H 2 & D & Wall & $\begin{array}{c}\text { D \& } \\
\text { W }\end{array}$ & Unref. & Totals \\
\hline Maritime Beaker vessels with stippled bands & 18 & 14 & 6 & & 3 & & 41 \\
\hline Maritime Beaker vessels with incised bands & & & 1 & & & & 1 \\
\hline Maritime Beaker vessels with stippled linear decoration & 8 & 5 & 4 & & & & 17 \\
\hline Vessels with stippled geometric decoration & 6 & 17 & 3 & 2 & & 8 & 36 \\
\hline Geometric incised vessels & 3 & 4 & 6 & 1 & & 1 & 15 \\
\hline Incised Palmela cups & & 7 & & 1 & & & 8 \\
\hline Incised calotte-shaped beakers & & & 5 & & & & 5 \\
\hline Stippled calotte-shaped cups & & & 1 & & & & 1 \\
\hline Ind. forms of incised bands & & 2 & & & & & 2 \\
\hline TOTALS & 35 & 49 & 26 & 4 & 3 & 9 & 126 \\
\hline TOTALS & 35 & 49 & 26 & 4 & 3 & 9 & 126 \\
\hline
\end{tabular}

Tab. 2. Typological distribution of the vessels of Penha Verde, by loci. H, Hut; D, Ditch; W, Wall; Unref., Unreferenced.

this technique. This gives a remarkable coherence to the group.

From the same circumscribed area, bone and malacological remains were also found, which have been already catalogued and published (Cardoso et al. 1996). Evidence indicates that the bottom of a Beaker hut was disturbed by deep ploughing, causing its materials to come to the surface. Amongst those was the remains of a domestic ox tooth, which was submitted for dating (Beta-296579: $4030 \pm 40 \mathrm{BP}$ ). The result is compatible with the chronology of other Beaker contexts known in the region, represented by the FM hut at Leceia (Tab. 2), despite of consisting entirely of incised pottery, traditionally considered to be more recent in the context of the Beaker pottery of Estremadura region.

3. Freiria: This open-air Beaker settlement was located on a gentle slope near a stream (Fig. 1) and consisted of various combustion structures and several huts, which yielded an abundant collection of decorated Beaker vessels. An Iron Age settlement was built on the same spot, followed by another during the Roman period, which occupied a much larger area (excavations led by Guilherme Cardoso and José d'Encarnação). The Beaker remains were preserved on an archaeological layer that was directly set upon the geological bedrock, associated to residential and combustion structures. In some cases, it was possible to recover smashed vessels in situ. This shows that, despite the existence of more modern constructions in certain places, the underlying prehistoric deposit was preserved, corresponding to a large and apparently open Beaker settlement. In fact, the Beaker productions are the only testimonies to Chalcolithic human presence found there.

Radiocarbon dating (Beta-260301: $3770 \pm$ $40 \mathrm{BP}$ and Beta-296577: $3630 \pm 40 \mathrm{BP}$ ) was obtained from two samples of indeterminate domestic animal bones, recovered from the southern zone of the excavated area, which were directly associated to the Beaker pottery materials. Considering the intervals from the two dates (Tab. 2), it seems that the occupation would have spanned for a period between the last quarter of the $3^{\text {rd }}$ millennium $\mathrm{BC}$ until the beginning of the next millennium.

This remarkable collection (Fig. 5) has a notable internal homogeneity, as it is characterized by the presence of incised decorations, which also appear in various maritime vessels, reproducing band motifs produced in other contexts by stippling. Similarly, there is a scarcity of stippled Palmela bowls in relation to the incised variety. Although dominated by incised large vessels (Tab. 1), the collection also includes some other types such as bottles and spherical vessels (large and small), that in some cases have not yet been marked in the Beaker records of Estremadura.

4. Cave of Ponte da Lage: This natural cave originated in a Cretaceous limestone and is located on the left bank of the Lage River (Fig. 


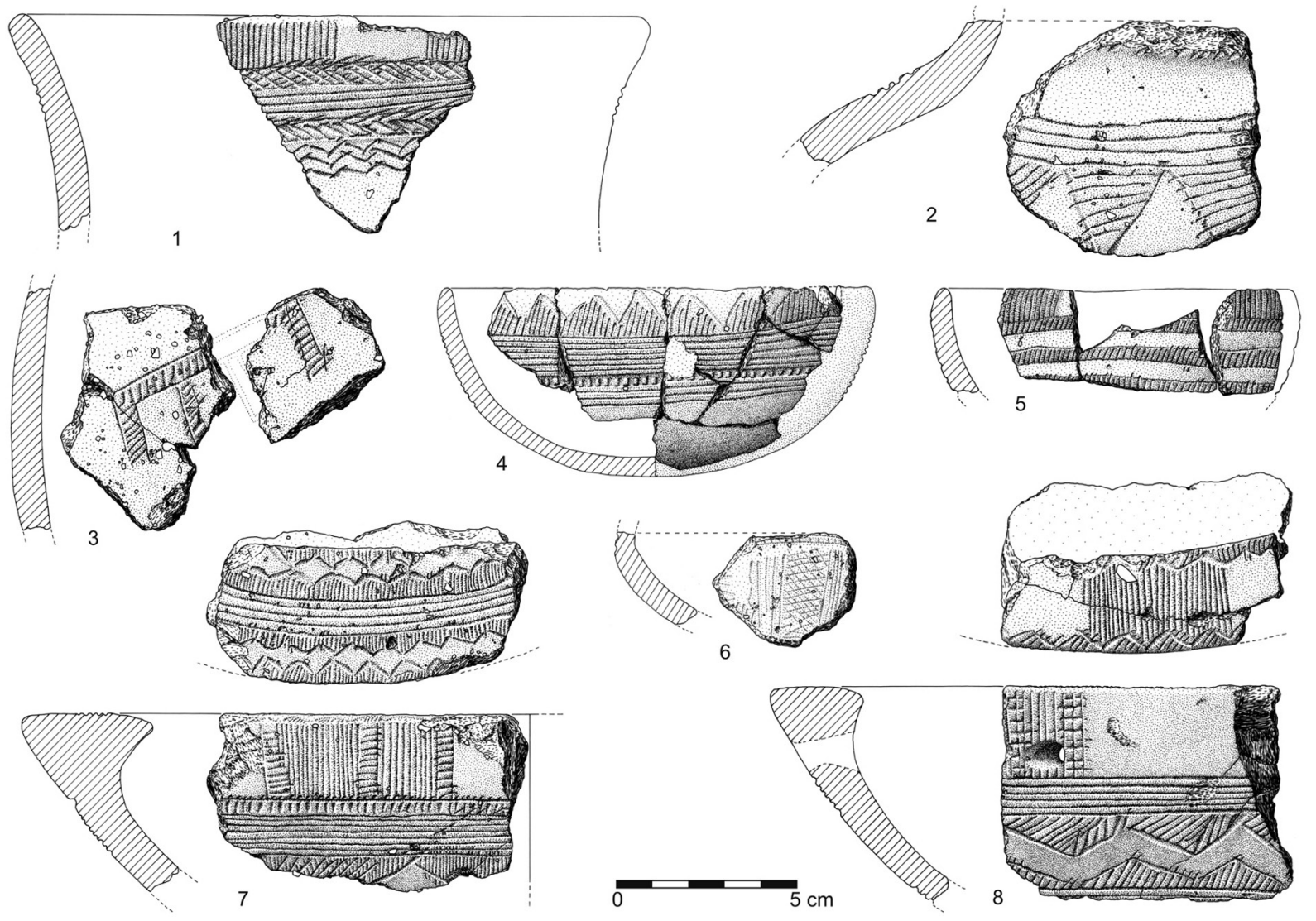

Fig. 4. Monte do Castelo. Beaker ceramics. Draws: B. L. Ferreira (CEACO/CMO).

1). It was explored in 1879 by Carlos Ribeiro and a vast panoply of Beaker materials from funerary context was gathered then along with residual remains of pre-Beaker and Bronze Age artefacts. The Beaker materials consisted of a copper tanged daggers and other metal pieces as well as an abundance of Beaker ceramics, dominated by incised vessels (Fig. 6, Tab. 1). This context was recently dated by the Project "The last hunter-gatherers and the first farming communities in the south of the Iberian Península and north of Morocco", co-directed by J. F. Gibaja and A. F. Carvalho (project PTDC/ HAH/64548/2006).

The chronology for these burials is the $3^{\text {rd }}$ quarter of the $3^{\text {rd }}$ millennium BC (Wk-25164: $3846 \pm 30 \mathrm{BP}$ ) and was confirmed by another AMS radiocarbon date, more recently obtained, by using, as the precedent, an human bone: Wk34424: $3833 \pm 26$ BP (Tab. 2).
5. Penha Verde: This settlement is located high up on the northern slope of the Sintra mountain (Fig. 1). A wall has been identified, though its full extension is not known and two huts with a circular ground plan, built with juxtaposed limestone slabs from area in the immediate vicinity (Zbyszewski and Ferreira 1958, 1959). The relationship between these two structures, and between them and the aforementioned wall is not clearly defined. It is thus not possible to confirm Harrison's (1977) claim that they form two bastions of a defensive system. One of these units (Hut 2) is associated with a deposit of domestic waste in a ditch outside the structure, which yielded many materials, and also with a paved floor in the surrounding area.

Before commenting on the distribution of Beaker ceramics over the various excavated areas, we should first discuss the conditions in which they were found. Although the excavation was 


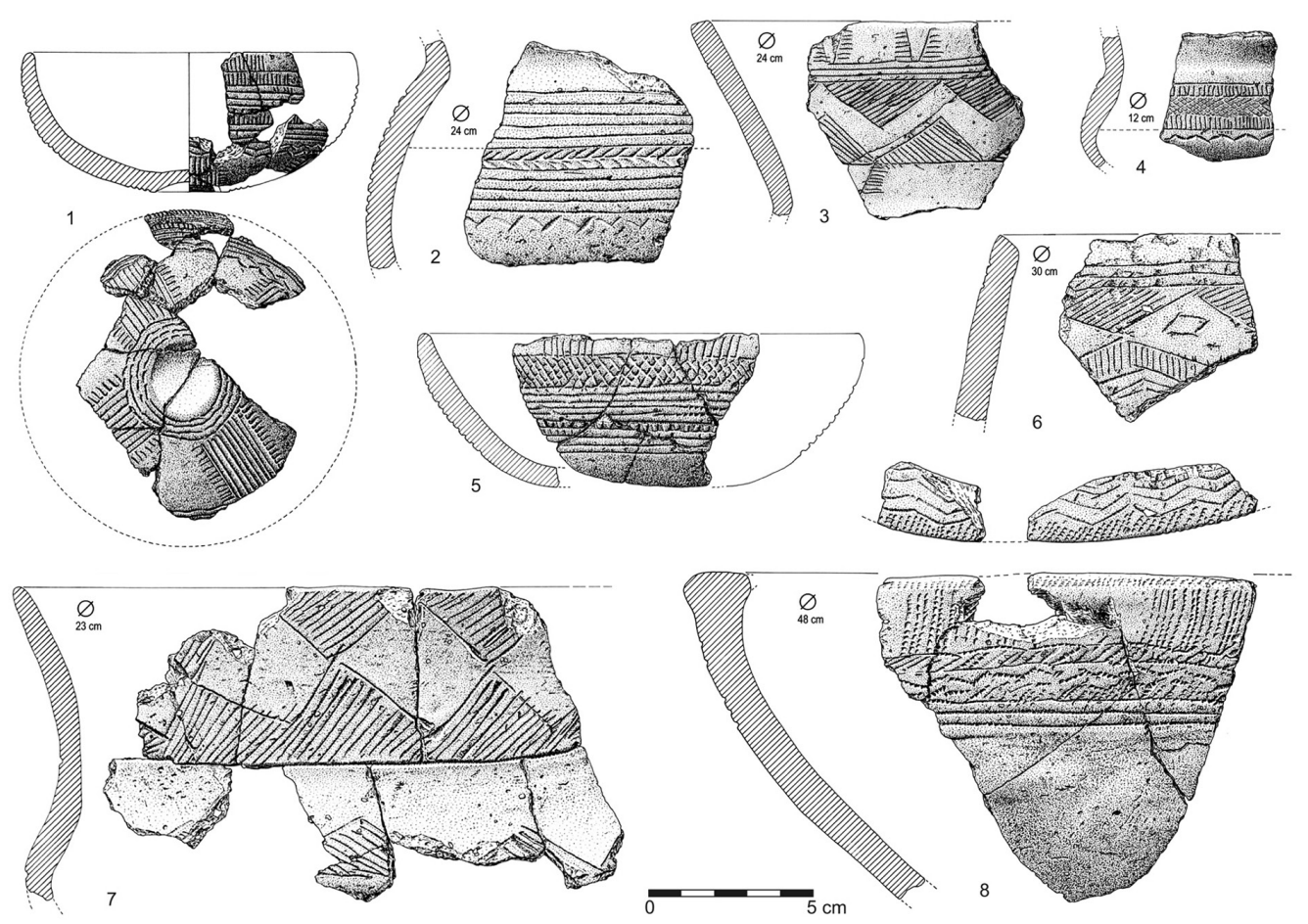

Fig. 5. Freiria. Beaker ceramics, some of them corresponding to smashed vessels in situ. Draws: B. L. Ferreira (CEACO/CMO).
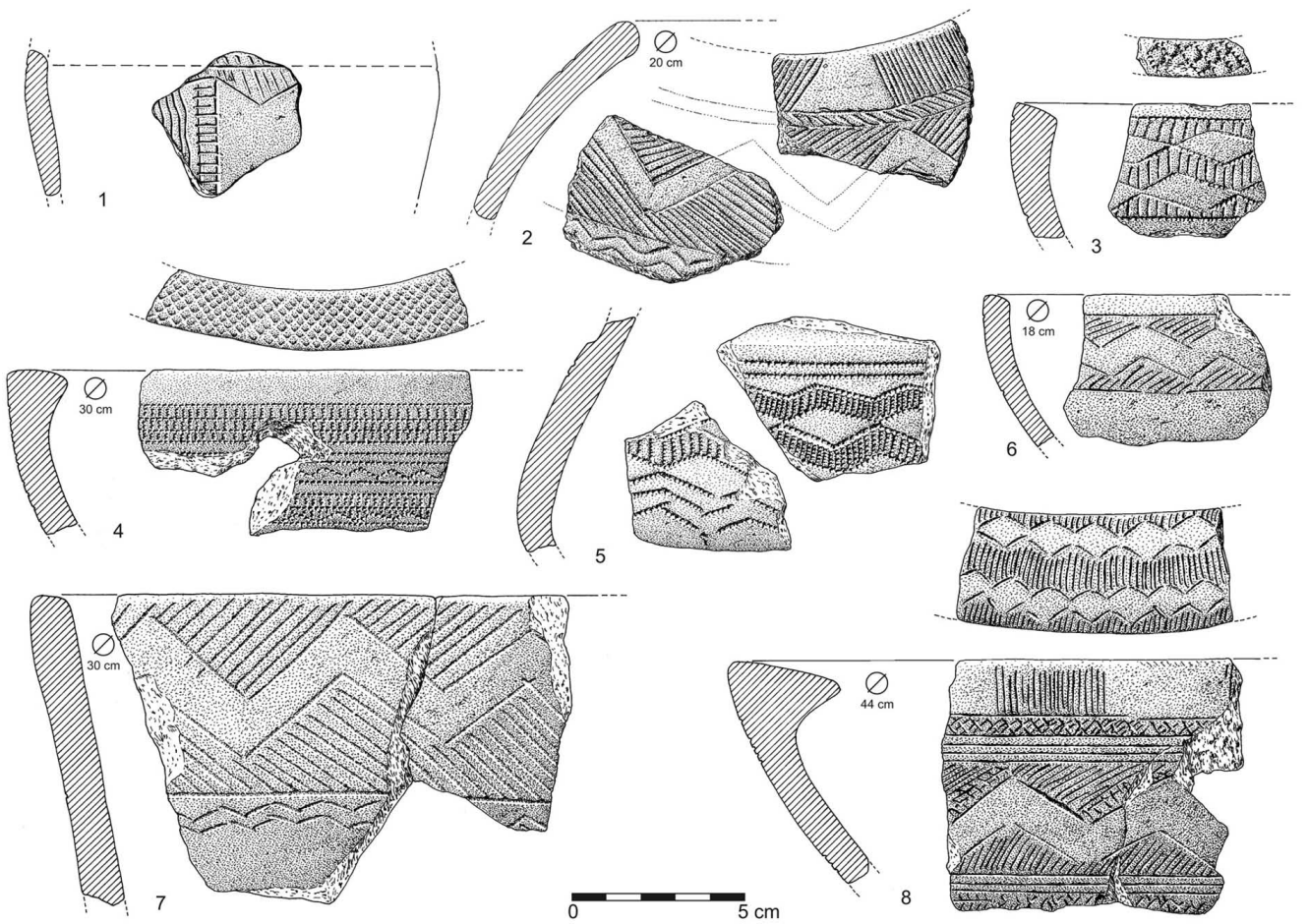

Fig. 6. Gruta da Ponte da Laje. Beaker ceramics. Draws: F. Martins (CEACO/CMO).

Trab. prehist., 71, N. ${ }^{\circ} 1$, enero-junio 2014, pp. 56-75, ISSN: 0082-5638 doi: $10.3989 /$ tp.2014.12124 
carried out in two consecutive years by the same team (Zbyszewski and Ferreira 1958, 1959), there were deficiencies in the records and in the recovery of the findings, as was explicitly recognised by one of the archaeologists (O. da Veiga Ferreira, personal communication). Despite that we can claim conclusively that the conditions of the deposit were not so different from those found at other recently excavated Chalcolithic settlements in Estremadura such as Zambujal and Leceia. In fact, the fragments decorated in local styles and those with Beaker decorations are often large, unrolled, and in an excellent state of conservation, which facilitates in some cases the total reconstitution of the original vessels, despite the fact that fragments came from different loci. This is what happened in the case of the Ditch, which was formed by waste that had come directly from Hut 2, as it can be seen in a sketch from the field notebook of $\mathrm{O}$. da Veiga Ferreira excavations (Fig. 7).

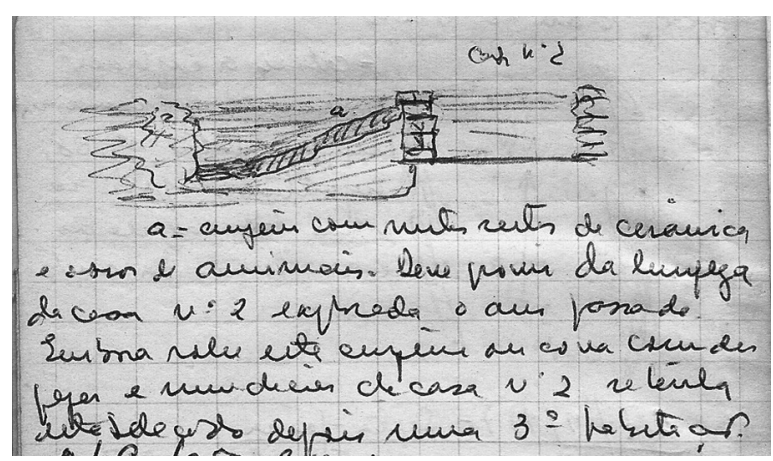

Fig. 7. Penha Verde. Sketch in the Field Carnet of O. da Veiga Ferreira concerning the second campaign of excavations (19/9/1958), showing the position of the Ditch (Fosso) outside Hut 2.

In light of this, there is no reason to reject the contemporaneity of the Beaker fragments and those decorated with a local style (acacia-leaf). The archaeological remains exhumed (Cardoso $2010 / 2011 b$ ) show, in fact, a close association between ceramics decorated in the regional style (the "acacia leaf" group) and the Beaker pottery. The distribution of Beaker pottery (Tab. 3, Fig. 8) shows a clear predominance of International stippled vessels group, which warrants further discussion: 94 of the 126 Beaker fragments catalogued are stippled (maritime vessels and other types).
Given the lack of any chronological reference framework in Penha Verde, a systematic AMS dating programme was carried out with carefully-selected bone samples taken from the various loci excavated. This programme ran between 2010 and 2011 (Cardoso 2010/2011b). The 6 dates obtained suggest three moments of occupation (Tab. 2): the first, represented by samples from the context 22/064, the Ditch and Hut 1 (statistically non-differentiable dates) is placed into the $3^{\text {rd }}$ quarter of the 3 rd millennium $\mathrm{BC}$; the second, represented by a sample from the pavement, a structure adjacent to Hut 2, is situated in the transition between the $3^{\text {rd }}$ and last quarter of the same millennium; and finally, the samples from Hut 2, atributed to the last quarter of the $3^{\text {rd }}$ millennium $\mathrm{BC}$, although there is an earlier date going back to the first use of the structure around the middle of that millennium.

In light of these observations it would seem that at Penha Verde, all Beaker vessels continued to be used over the course of the second half of the 3rd millennium $\mathrm{BC}$, corresponding to the occupation of the two dwelling units -Hut 1 and Hut $2-$ although the later seems to have been occupied for longer. The more recent stage of use, from the end of the $3^{\text {rd }}$ millennium $\mathrm{BC}$, could be concomitant with the production of incised vessels, especially Palmela bowls, at the same time as maritime Beakers were being produced, corresponding to the last phase of the filling of the Ditch, that resulted from the waste produced there.

The typological analysis performed on Penha Verde emphasises the difficulty in establishing rigid operative framework for Beaker output, as the different types of ceramic productions as in most cases have coexisted, involving quite broad chronologies, as was emphasised by the results presented in this paper.

6. Moita da Ladra: This fortified settlement is located at the top of a basalt chimney overlooking the inner estuary of the Tagus River (Figs. 1 and 9). Vestiges of metalworking have been found, associated with the only occupation phase that has been identified, corresponding to a series of decorated ceramic vessels that associating local patterns, as acacia-leaf pattern, with Beaker productions (Tab. 1). No other Chalcolithic or more recent productions have been identified amongst the findings (Cardoso and Caninas 2010) indicating the absence of significant interference or remobilizations. It can be seen that almost all 


\begin{tabular}{|c|c|c|c|c|c|}
\hline Site & Context & Laboratory & C14 date & $2 \sigma$ cal BC & Sample \\
\hline & FM HUT & Sac-1317 & $4220 \pm 50 \mathrm{BP}$ & $2920-2630$ & Mammal bones \\
\hline & FM HUT & Beta-260297 & $4140 \pm 40 \mathrm{BP}$ & $2880-2590$ & Humerus of Sus sp. \\
\hline & FM HUT & Beta-260299 & $4100 \pm 40 \mathrm{BP}$ & $2870-2500$ & Metacarpal of Bos taurus \\
\hline \multirow[t]{7}{*}{ Leceia } & FM HUT & Sac-1317 & $4220 \pm 50 \mathrm{BP}$ & $2920-2630$ & Mammal bones \\
\hline & FM HUT & Beta-260297 & $4140 \pm 40 \mathrm{BP}$ & $2880-2590$ & Humerus of Sus sp. \\
\hline & FM HUT & Beta-260299 & $4100 \pm 40 \mathrm{BP}$ & $2870-2500$ & Metacarpal of Bos taurus \\
\hline & EN HUT & ICEN-1241 & $3950 \pm 90 \mathrm{BP}$ & $2850-2150$ & Mamal bones \\
\hline & EN HUT & Beta-260295 & $3840 \pm 40 \mathrm{BP}$ & $2460-2160$ & Calcaneus of Bos taurus \\
\hline & EN HUT & Beta-260296 & $3980 \pm 40 \mathrm{BP}$ & $2620-2350$ & Radium of Sus sp. \\
\hline & & Wk - 34424 & $3833 \pm 26 \mathrm{BP}$ & $2331-2200$ & Human radius \\
\hline \multirow[t]{2}{*}{ Freiria } & & Beta-260301 & $3770 \pm 40 \mathrm{BP}$ & $2340-2040$ & Mammal bones \\
\hline & & Beta-296577 & $3630 \pm 40 \mathrm{BP}$ & $2130-1890$ & Mammal bones \\
\hline \multirow[t]{6}{*}{$\begin{array}{l}\text { Ponte da Lage } \\
\text { cave }\end{array}$} & & WK -25164 & $3846 \pm 30 \mathrm{BP}$ & $2460-2210$ & Young human skull \\
\hline & & Wk - 34424 & $3833 \pm 26 \mathrm{BP}$ & $2331-2200$ & Human radius \\
\hline & $\begin{array}{c}\text { Ditch } \\
\text { (related to Hut 2) }\end{array}$ & Beta-276400 & $3970 \pm 40 \mathrm{BP}$ & $2580-2350$ & Third lower molar of Ovis/Capra \\
\hline & Context 22/064 & Beta-260300 & $4000 \pm 40 \mathrm{BP}$ & $2590-2460$ & Lower canine of Sus scrofa \\
\hline & & Sac-2122 & $3700 \pm 50 \mathrm{BP}$ & $2270-1950$ & Mammal bones \\
\hline & & Sac-2123 & $3700 \pm 50 \mathrm{BP}$ & $2270-1950$ & Mammal bones \\
\hline \multirow[t]{6}{*}{ Penha Verde } & Hut 1 & Beta-276399 & $3890 \pm 40 \mathrm{BP}$ & $2470-2210$ & $\begin{array}{l}\text { First or second lower molar of } \\
\text { Bos taurus }\end{array}$ \\
\hline & Hut 2 & Beta-296578 & $3700 \pm 30 \mathrm{BP}$ & $2200-1980$ & Humerus of Bos taurus \\
\hline & Hut 2 & Beta-296580 & $3680 \pm 40 \mathrm{BP}$ & $2200-1950$ & Metatarsal of Cervus elaphus \\
\hline & $\begin{array}{c}\text { Pavement } \\
\text { (related to Hut 2) }\end{array}$ & Beta-276398 & $3830 \pm 40 \mathrm{BP}$ & $2460-2150$ & Third lower molar of Bos taurus \\
\hline & $\begin{array}{l}\text { Ditch (related to } \\
\text { Hut 2) }\end{array}$ & Beta-276400 & $3970 \pm 40 \mathrm{BP}$ & $2580-2350$ & Third lower molar of Ovis/Capra \\
\hline & Context 22/064 & Beta-260300 & $4000 \pm 40 \mathrm{BP}$ & $2590-2460$ & Lower canine of Sus scrofa \\
\hline \multirow[t]{4}{*}{$\begin{array}{l}\text { Moita da } \\
\text { Ladra }\end{array}$} & & Sac-2122 & $3700 \pm 50 \mathrm{BP}$ & $2270-1950$ & Mammal bones \\
\hline & & Sac-2123 & $3700 \pm 50 \mathrm{BP}$ & $2270-1950$ & Mammal bones \\
\hline & & Sac-2370 & $3930 \pm 80 \mathrm{BP}$ & $2830-2150$ & Mammal bones \\
\hline & & Sac-2371 & $3810 \pm 60 \mathrm{BP}$ & $2460-2050$ & Mammal bones \\
\hline \multirow[t]{4}{*}{$\begin{array}{l}\text { Verdelha dos } \\
\text { Ruivos cave }\end{array}$} & Grave 2 & GrN-10972 & $4100 \pm 60 \mathrm{BP}$ & $2880-2490$ & Human bones \\
\hline & Grave 4 & GrN-10973 & $4000 \pm 35 \mathrm{BP}$ & $2620-2460$ & Human bones \\
\hline & Grave 2 & GrN-10971 & $3960 \pm 40 \mathrm{BP}$ & $2580-2430$ & Human bones \\
\hline & undeterminate & ICEN-1242 & $3940 \pm 45 \mathrm{BP}$ & $2570-2300$ & Human bones \\
\hline
\end{tabular}

Tab. 3. Settlements of Lower Estremadura region (Portugal) discussed in this work. Radiocarbon dates. 


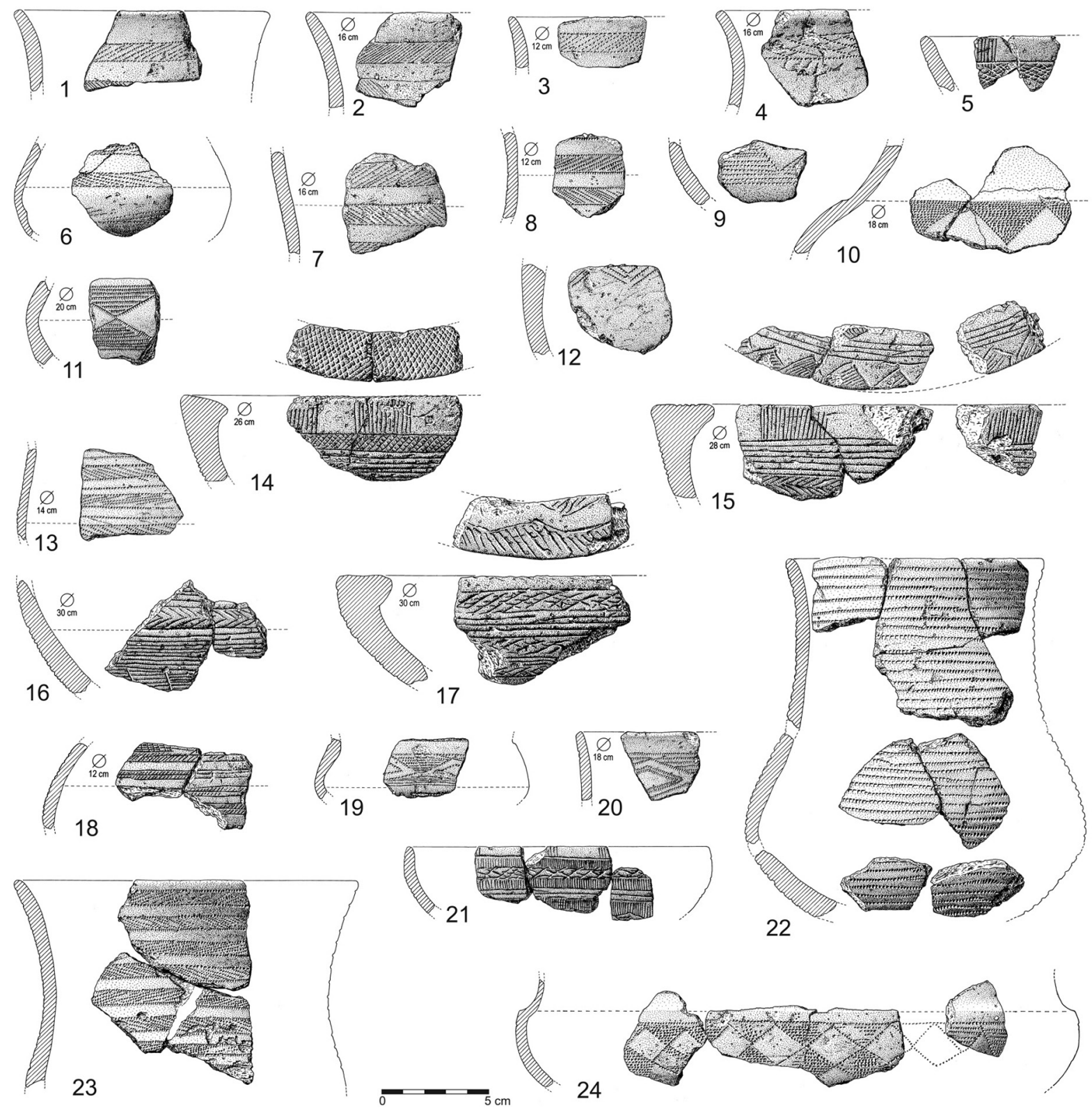

Fig. 8. Penha Verde. Beaker ceramics from Hut 1 (n. $\left.{ }^{\circ} 1-7\right)$, Hut 2 (n. $\left.{ }^{\circ} 8-14\right)$ and Ditch (n. ${ }^{\circ}$ 15-20). Draws: B. L. Ferreira $(\mathrm{CEACO} / \mathrm{CMO})$.

the Beaker fragments are decorated with the stippled technique, and amongst them, there is a clear predominance of maritime Beakers (Fig. 10). The incised technique is only represented by one fragment of a shoulder pot.

Four radiocarbon dates were obtained for this occupation based on samples of animal bones from the terrestrial biosphere (Tab. 2). The results shows that the main utilisation of the site occurs along the last quarter of the $3^{\text {rd }}$ millennium BC.

7. Cave of Verdelha dos Ruivos: In this small natural funerary cave the unique occupation identified is represented by 44 Beaker tumulations, distributed across four different levels. Although there is a reference to bodies systematically deposited in lateral decubitus in holes and covered with 

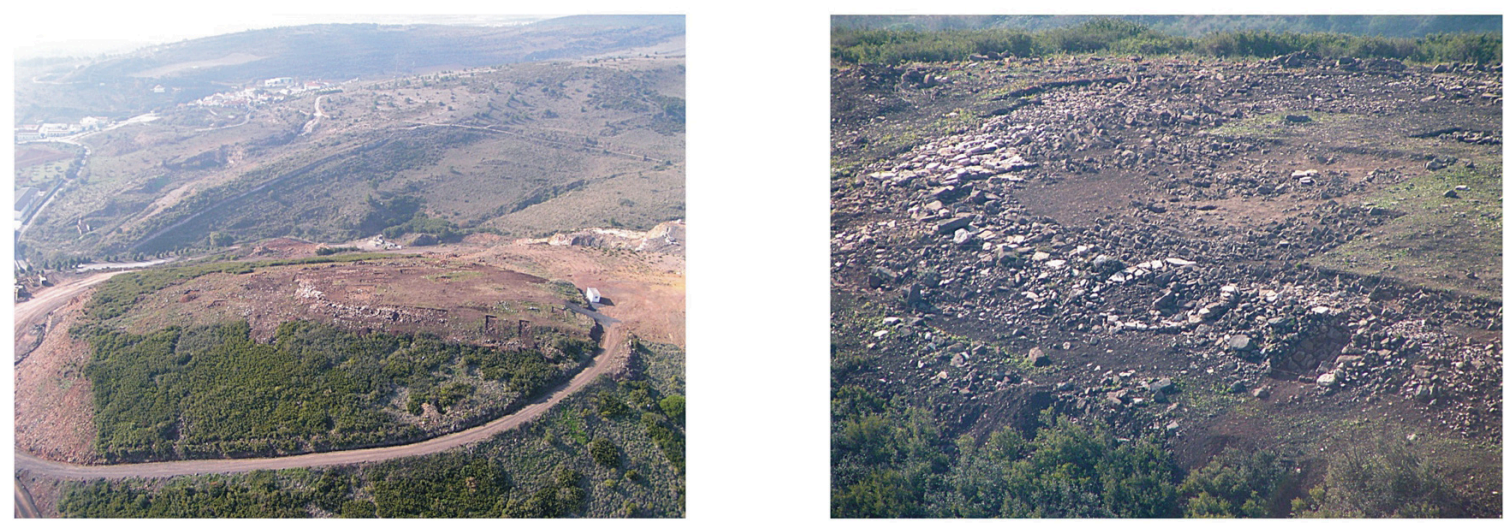

Fig. 9. Moita da Ladra. Basaltic chimney in the top of which the fortified settlement was built. Photos: J. L. Cardoso.
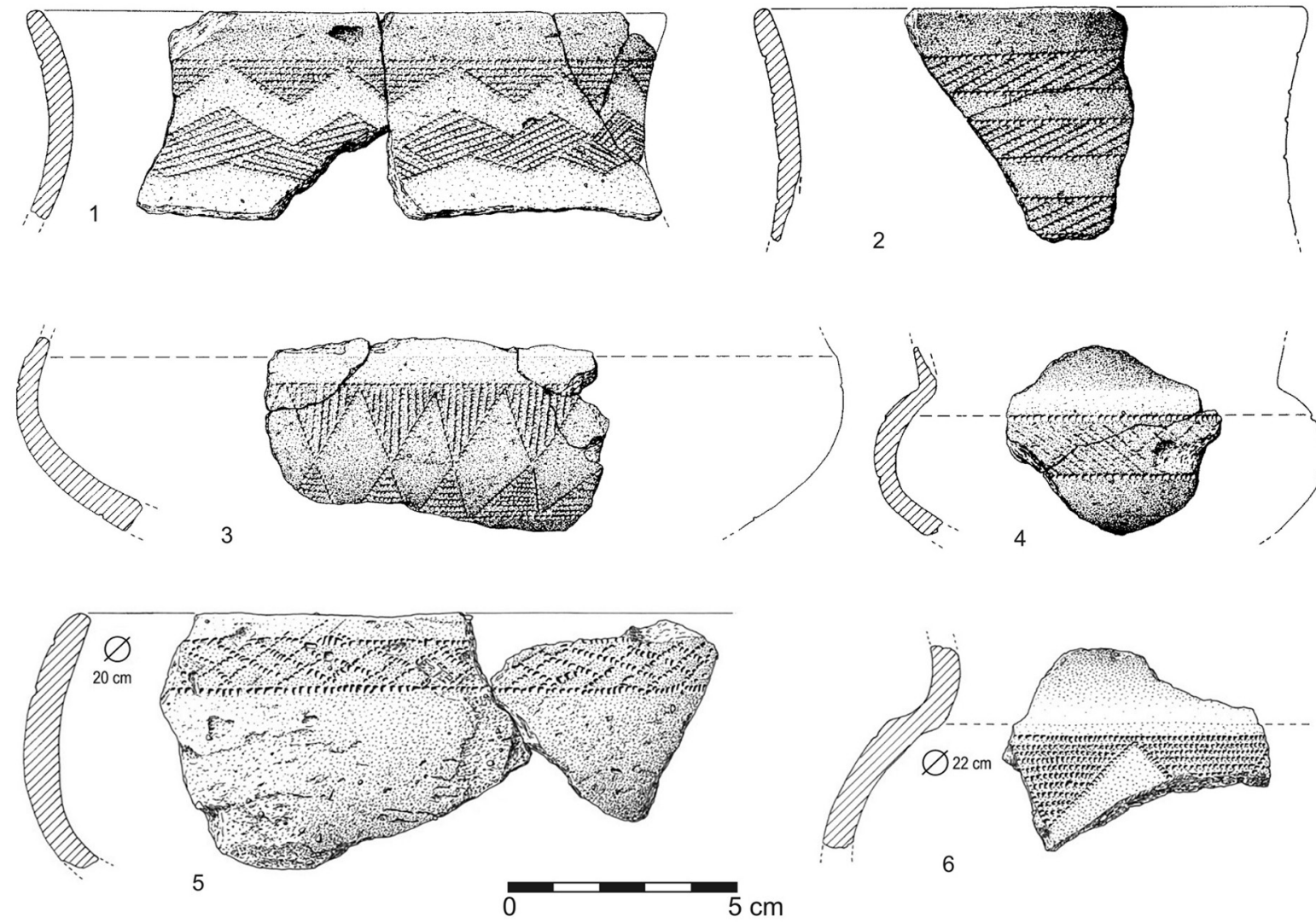

Fig. 10. Moita da Ladra. Beaker ceramics Drawns: B. L. Ferreira (CEACO/CMO).

slabs, we do not know the exact identification of each burial as they do not appear on published plans. But the smallness of the natural cavity and the use sequence suggests that the cavity was a necropolis for a limited period of time. Published archaeological record (Leitão et al. 1984) indicated that decorated productions were dominated by incised technique (Fig. 11) applied particularly to Palmela bowls. According to traditional view this would confer a late chronology to the whole set, 
reinforced by the residual presence of the traditionally earlier productions (maritime Beakers and other vessels with stippled linear patterns) (Tab. 1).

Four radiocarbon dates (Tab. 2) were obtained from human bones (Cardoso and Soares 1990/1992: Quadro 1). The main utilisation of the cave as a funerary space occurs mainly along the $2^{\text {nd }}$ quarter of the $3^{\text {rd }}$ millennium cal $\mathrm{BC}$ and in the transition to the second half of the same millenium. The absolute chronology does not agree with the relative modernity of the pottery, according to the traditional typological approach. In fact, the uniformity of dates obtained and the overall coherence of the recovered remains, and the same characteristics of the funereal depositions reinforces this conclusion.

\section{DISCUSSION}

1. The first set of questions that are raised concerns chronology, status and significance of the Beaker incised productions. In light of the information presented we can conclude that incised productions are dominant at the sites of Leceia (EN hut), Freiria, and the funerary cave of Ponte da Lage, where they were produced throughout the $2^{\text {nd }}$ half of the $3^{\text {rd }}$ millennium $\mathrm{BC}$ and extended even into the beginning of the $2^{\text {nd }}$ millennium BC. The exceptions are the funerary cave of Verdelha dos Ruivos, which corresponds mainly to the $2^{\text {nd }}$ quarter/middle of the $3^{\text {rd }}$ millennium BC, and Monte do Castelo, but the archaeological conditions of the recovered materials at this small site demands prudence. Thus, in spite of the similarity of the ceramic record, the radiocarbon dates shows that the incised productions cover a wide timespan, ranging from the end of first half till the late $3^{\text {rd }}$ millenium BC (Fig. 12). This conclusion contradicts the traditional modernity that is attributed to these kind of productions, associated to small communities (probably family-based) spread across the fertile lands of the region.
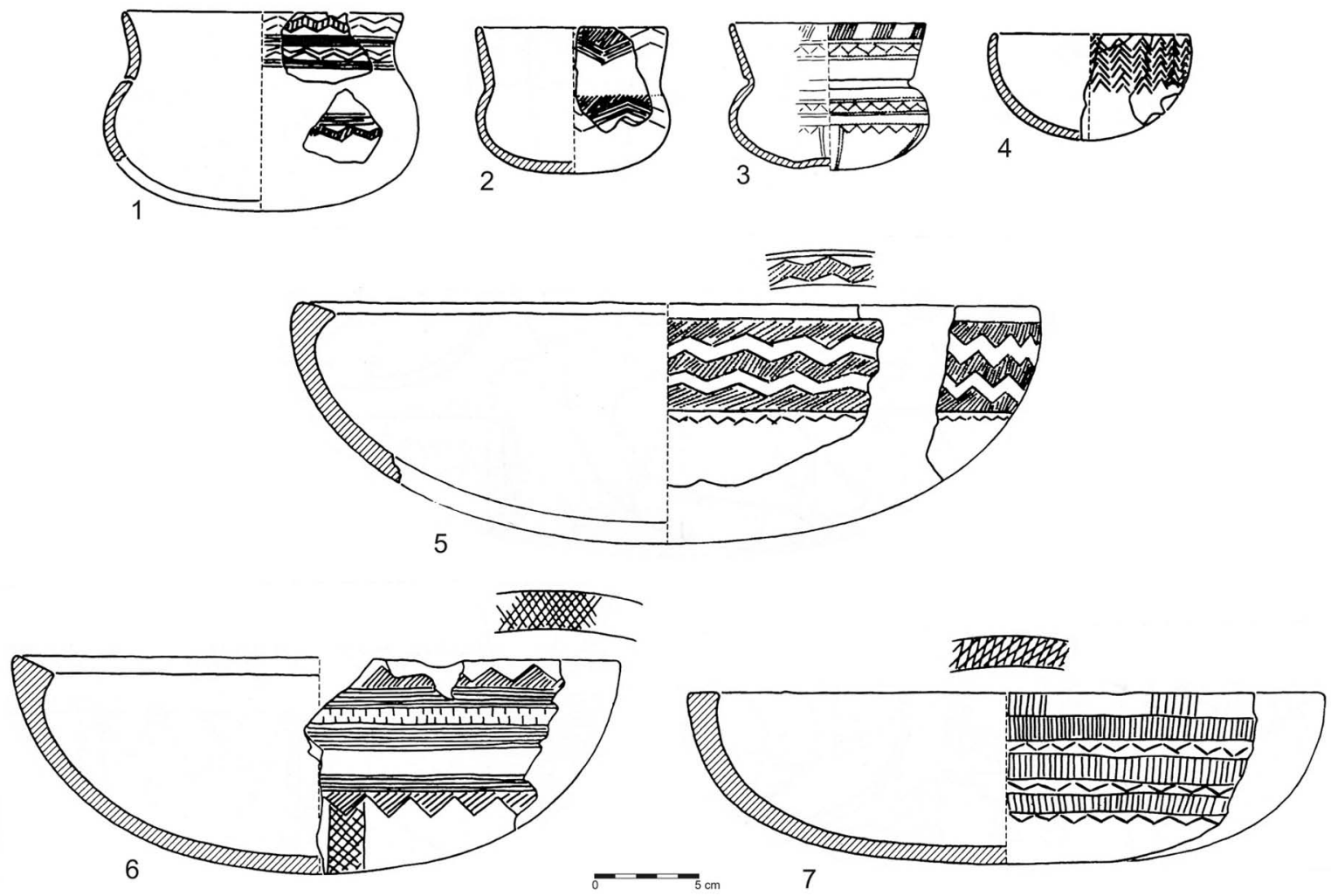

Fig. 11. Verdelha dos Ruivos cave. Beaker ceramics (after Leitão et al. 1984). 


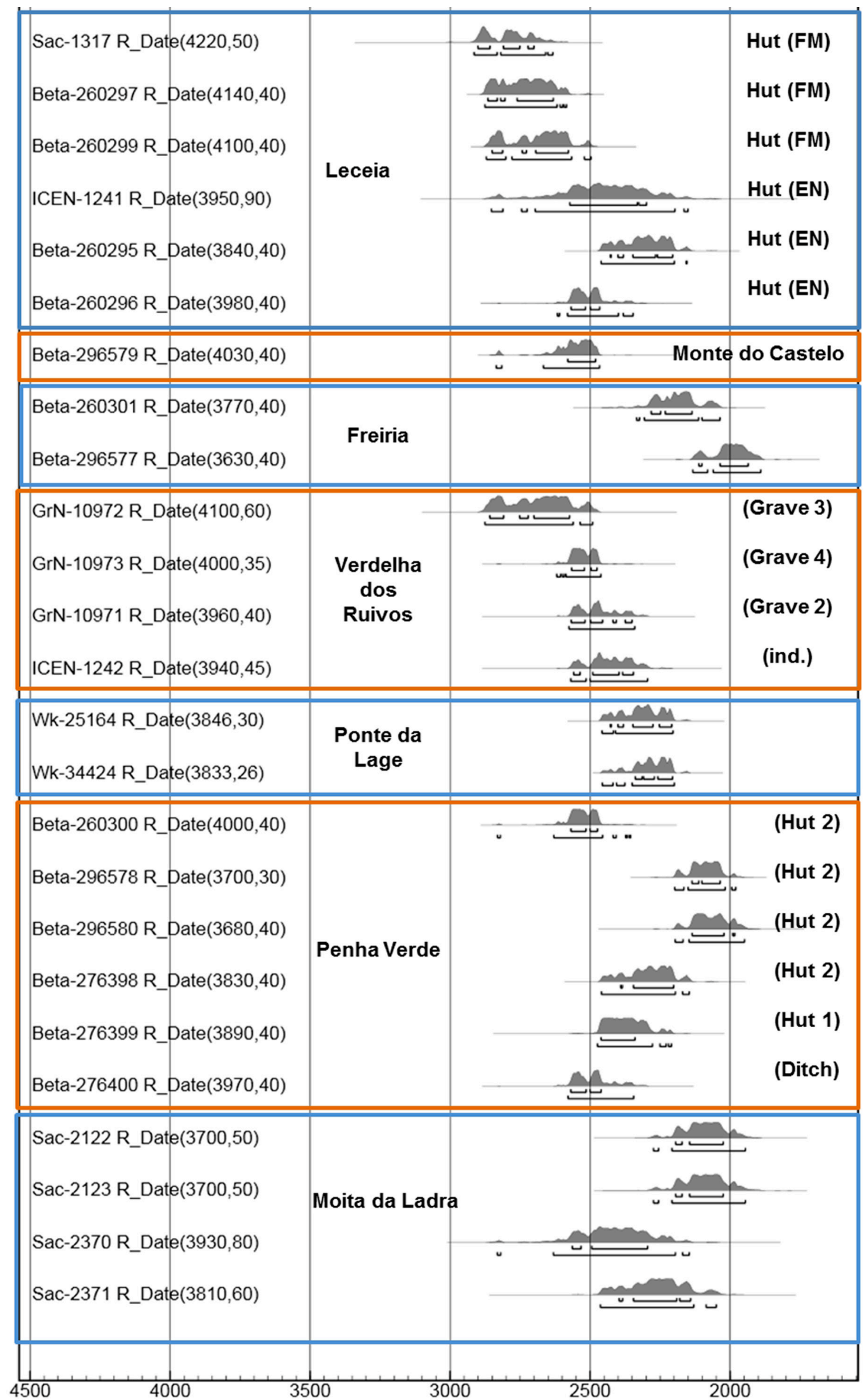

Fig. 12. Graphic representation of probability distributions of calendar dates using the OxCal v4.1.7 program (Bronk Ramsey 2009) and the calibration curve IntCal09 (Reimer et al. 2009).

Trab. prehist., 71, N. ${ }^{\circ}$ 1, enero-junio 2014, pp. 56-75, ISSN: 0082-5638 doi: $10.3989 /$ tp.2014.12124 
2. Another important matter is the status and significance of the maritime Beakers and associated vessels with stippled geometric decorations. Some of the elevated fortified sites, such as the settlement at Leceia, were founded at the beginning of the $3^{\text {rd }}$ millennium $\mathrm{BC}$ and had already gone into decline when the first Beaker vessels appeared inside its walls during the $3^{\text {rd }}$ quarter of the millennium. In other fortifications, founded ex-novo throughout the $2^{\text {nd }}$ half of that millennium, as is the case of Moita da Ladra and Penha Verde, maritime Beakers are also the most representative. In both sites, as well as Leceia, the Beaker productions are associated with local-style ceramics ("acacia-leaf" pattern).

These two sites confirm the continuation of fortification practice by bearers of Beaker productions during the $2^{\text {nd }}$ half of the $3^{\text {rd }}$ millennium BC. Despite the tendency for a disinvestment in the maintenance of some previously flourishing fortifications, such as Leceia, there are still a number of strategic sites for the control of circulation of people and goods builted and occupied in that time.

3. Fig. 12 shows the results of the probability distribution of all the calibrated radiocarbon dates presented above. It is clear that the two main types of Beaker productions could have coexisted in both space and time. These two groups developed in close relation with the nature of their respective sites. Thus, while the fortified sites are characterised by Beaker productions dominated by the maritime vessels and by vessels with geometric decoration, also obtained by stippling, the productions found in the small family-based domestic sites on the more gentle slopes are largely dominated by the incised technique. This suggests one immediate conclusion. If we admit that different material cultures may correspond to human groups with different cultural characteristics, it is tempting to interpret the communities settled in the fortified sites as socially differentiated from those living at the same time on the vast adjacent territories. The generally superior quality of the Beaker productions found in fortified sites, compared to incised vessels found elsewhere, supports some kind of economic and social differentiation between these two groups of people. In fact, this situation has parallels with that found a millennium and a half later in the same region, with the populations that occupied it throughout the Late Bronze Age. That is to say, although ornate burnished ceramics occurred in the higher areas where the elite lived such vessels were scarce or even non-existent in the open agro-pastoral sites (Cardoso 1999/2000). This is the case with the agricultural community of Abrunheiro, Oeiras, where there is not a single fragment of such ceramic ware amongst the thousands of pieces collected, despite the fact that such productions were at their peak at the same time and region $\left(10 / 9^{\text {th }}\right.$ century $\left.\mathrm{BC}\right)$ (Cardoso 2010/2011c)

Thus, social differentiation can be observed in Beaker communities, with the emergence of a dominant segment that occupied (and in some cases built) the walled sites situated on the top of elevations in Lower Estremadura, such as Zambujal, Penha Verde, Moita da Ladra and Leceia. This group is clearly represented by the wellknown panoply that includes tanged daggers, wristguards, Palmela points and, probably, for the first time, gold jewellery. This situation contrasts with that of the small farming communities that worked at the same time the fertile lands nearby. Thus it is not surprising that, in those sites, the finer artefacts destined for drinking, such as maritime Beakers, were replaced by thicker and usually bigger vessels, besides those destined for the storage of cereals, with incised decorations.

Another evidence of the contemporaneousness of the two main types of vessels (small to medium maritime Beakers versus medium to large incised vessels) is that they generally appear in association, though in very different relative quantities, according to the nature and function of the respective settlements: walled settlements versus small farming communities.

The two natural funerary caves mentioned and dated yielded Beaker productions exclusively (Verdelha dos Ruivos cave) or almost exclusively (Ponte da Lage cave); in the case of Ponte da Lage cave, only one individual grave was found at the entrance to the cave during the excavations of the 1950s dating from the Late Neolithic/Early Chalcolithic (Vaultier et al. 1959); thus, we can be sure that all the radiocarbon dates correspond to Beaker contexts related to the funerary depositions found in the interior of the cave by Carlos Ribeiro in 1879.

4. The antiquity of Beaker pottery collected at the FM hut at Leceia is one of the most important aspects of this study, following the demonstration of contemporaneity of the incised and 
stippled Beaker productions. In Portugal various dates stand out due to their respective absolute chronologies, compatible with the chronology obtained for the FM hut at Leceia. For example, there is a date obtained for a Beaker occupation of the settled area of Porto Torrão (Ferreira do Alentejo) (Arnaud 1993; Cardoso and Soares 1990/1992). This yielded the result of ICEN $60 / 61-4220 \pm 45 \mathrm{BP}$, which, after being calibrated corresponds to the interval of 2823-2658 cal BC $2 \sigma$. This set is represented almost exclusively by vessels with stippled decorations, applied to maritime vessels.

Recently published dating of Beaker occurrences in Crasto de Palheiros (Bettencourt 2011: 370) related to Layer I of the Inner Unit, where 18 Beaker vessels of various types (maritime, stippled geometric and incised) were collected confirm this antiquity: CSIC-1280: $4087 \pm 34 \mathrm{BP}$ and UA-22284: $4035 \pm 45 \mathrm{BP}$ corresponding to the intervals, at $2 \sigma$, of 2861-2494 cal BC and 2850-2466 cal BC respectively.

We should stress the diversity and the contemporaneousness of the Beaker vessels found in Tumulus 1 of Chã do Carvalhal (Baião), which reinforces the conclusions from the FM hut at Leceia: in this probably single grave were found fragments of a classic stippled maritime vessel, a stippled geometric vessel, two vessels with incised decoration, and one Palmela bowl with stippled decoration, as well as another one not decorated (Cruz 1992) with seven copper artefacts (two daggers and five Palmela points).

Finally, still in the northeast of the Iberian Peninsula, dates were also obtained for the Beaker contexts of Level 1 of Buraco da Pala: ICEN310: $4120 \pm 80$ BP (2888-2490 cal BC); ICEN311: $4120 \pm 50$ BP $(2876-2572$ cal BC); GrN-19101: $3955 \pm 25$ BP (2569-2348 cal BC). The associated materials reveal local interpretations of the decorative motifs of classic Beaker vessels (Sanches 1997), which means that the first Beaker vessels were already known in this region, despite the relative antiquity of their succedaneous.

Given the above mentioned we may conclude that the North of Portugal, despite the few Beaker occurrences recorded, has contributed decisively to demonstrate the antiquity of Beaker productions, which clearly date back to the $2^{\text {nd }}$ quarter of the $3^{\text {rd }}$ millennium BC. A similar antiquity was also found in southern Portugal (Por- to Torrão, Zambujal, Leceia), and the respective pottery sets are also remarkably diverse, in terms of the kinds of vessels found and decorative techniques used.

\section{CONCLUSIONS}

After the presentation of the materials and sites that form the empirical basis of this study, and the discussion of the results obtained, integrated within the regional and superregional context, the following conclusions may be drawn concerning the organization of Chalcolithic society in Lower Estremadura.

1. The comparison of chronometric and archaeological results described above suggests that the first Beaker productions in the region of Lower Estremadura (between about 2700 and 2600 BC) coexisted, with lower interaction, with Chalcolithic populations that lived in some fortified sites, as shown by the chronology of the FM hut at Leceia. This is the same period in which fluted pottery typical of the Early Chalcolithic of Estremadura was still used inside this fortified settlement. But in other cases this coexistence was followed by interaction with the inhabitants of those already-existing fortified sites (as found in the fortified Chalcolithic settlement of Zambujal).

This interaction persisted throughout the whole Full Chalcolithic (represented by the characteristic "acacia-leaf" ceramic pattern) until the end of the $3^{\text {rd }}$ millennium $\mathrm{BC}$, as can be seen in almost all the fortified settlements of Lower Estremadura.

2. Throughout the whole second half of the $3^{\text {rd }}$ millennium $\mathrm{BC}$ this interaction would have resulted in the segregation of finer artefacts (represented by maritime and geometric stippled vessels) in strategically-located and fortified sites (in this work, represented by Leceia, Penha Verde and Moita da Ladra). These sites were active until the beginning of the $2^{\text {nd }}$ millennium $\mathrm{BC}$ where the most important members of the community lived. Incised ceramic group proliferated in adjacent fertile lands, farmed by numerous family-based agricultural-pastoral activities. Its general inferior quality suggest other socio-economic conditions. Thus open sites like Freiria and Monte do Castelo were only apparently self-sufficient. The close affinities between them (shown 
by the similarities in the ceramic ware, dominated by the incised technique and the abundance of large storage vessels) suggests that they were integrated into economic networks administered by the inhabitants of the first type of settlements. This was the model which around a millenium and a half later, would be fully adopted during the Late Bronze Age in the same geographic area. This would, therefore, have been a segmented society, segregated into two interdependent groups making part of the same social formation.

3. The complexity of the Beaker phenomenon in the region does not fit well with the model of three successive in time classic distinct groups (International Group; Palmela Group and Incised Group), as shown by the results obtained at this study. Moreover its remarkable antiquity in the region, proved by AMS dating and the diversity of types of respective Beaker materials, where very different productions coexist, has parallels in the South (settlement of Porto Torrão, already mentioned in that work) and North of Portugal, namely Crasto de Palheiros and Buraco da Pala (Sanches 1997, 2008; Bettencourt 2011), and also in Spain (Harrison and Mederos Martín 2001).

4. On a more global approximation to the socio-cultural reality during the $2^{\text {nd }}$ half of the $3^{\text {rd }}$ millennium BC in Lower Estremadura, we may consider that if Beaker society was segmented with two clearly-differentiated components, it may have corresponded nevertheless to a cultural entity as a whole with its own characteristics, at least in the region under appreciation. In fact, based on the archaeological record identified at Leceia since the end of the Early Chalcolithic it is possible to admit that that two communities with different cultural roots coexisted with a lower level of interaction (and conflict) during the course of the Chalcolithic in Lower Estremadura. And the reinforcement of this coexistence, with the increment of interaction, between Beaker and indigenous productions at the majority of walled settlements of Lower Estremadura, during the $2^{\text {nd }}$ half of the $3^{\text {rd }}$ millennium BC shows that inherent interaction did not appear to have been conflictive. On the contrary, there are examples of decorated ceramics that congregates Beaker and local patterns.

Therefore this is a question of recognising the reasons that differentiated the bearers of Beaker productions, from those who did not possess or use them in the same time and region. In fact, despite being located at in the region that is the heart of the highest concentration Beaker material, some settlements such as Penedo de Lexim (Mafra) and Outeiro Redondo (Sesimbra) present an almost total absence of Beaker productions during that period (Arnaud 1974/1977; Sousa 2010; Cardoso 2010; Cardoso et al. 2010/2011). This conclusion is important having in consideration the significative excavated areas in both settlements. In fact, the possibility that there may have been coexistence of these two social formations with distinct cultural roots was suggested for the first time about the communities that lived inside the fortification of Leceia and in the two Beaker huts found on the periphery of the walled line (Cardoso 1997/1998), and it was taken up again in the context of other contributions (Cardoso 2000b, 2001, 2004, 2005, 2010/2011a, 2010/2011b).

5. Absolute chronology of the earliest Beaker contexts in Estremadura is now well-established as having occurred circa $2700 / 2600$ cal BC prior to the transition from the traditional Early to the Full Chalcolithic. This transition has been established in Leceia between 2600/2500 cal BC (Cardoso and Soares 1996). Thus the tripartite phasing of the Chalcolithic (Early, Full and Late) is no longer admissible in this region, as it means that the Beaker culture would have emerged only in the third and last phase of that sequence (Soares and Silva 1974/1977). On the contrary, the Beaker "phenomenon" seems to have a parallel but independent course regarding the development of the Chalcolithic in this region, represented only by two successive stages (Early and Full/Late Chalcolithic) each of them characterised by two particular types of ceramic productions with regional expression (channelled and "acacia-leaf" patterns).

\section{ACKNOWLEDGMENTS}

Dr. A. M. Monge Soares provided the radiocarbon dates of Moita da Ladra, and the Fig. 12 presented in this work, with the collaboration of António M. Matos Martins, besides the critical appreciation of the manuscript. C. Tavares da Silva read a preliminary version of this work. Dr. Miguel Kunst gave me the information regarding absolute chronology and stratigraphic distribution of Beaker productions in the settlement of Zam- 
bujal (Torres Vedras). Dr. Rui Boaventura revised the english version. And, last but not least, Dr. Isaltino Morais, Mayor of the Oeiras Municipality, provides support for the preparation of the present work.

\section{BIBLIOGRAPHY}

Arnaud, J. M. 1974/1977: "Escavações no Penedo do Lexim (Mafra)/1975". O Arqueólogo Português Série III, 7/9: 398-406.

Arnaud, J. M. 1993: “O povoado calcolítico do Porto Torrão (Ferreira do Alentejo): síntese das investigações realizadas". Vipasca 2: 41-60.

Bettencourt, A. M. S. 2011: "El vaso campaniforme en el norte de Portugal. Contextos, cronologias y significados". In M. P. Prieto-Martínez and L. Salanova (eds.): Las comunidades campaniformes en Galicia. Cambios sociales en el III y II milénios $B C$ en el NW de la Península Ibérica. Diputación de Pontevedra. Pontevedra: 363-374.

Bronk Ramsey, C. 2009: "Bayesian analysis of radiocarbon dates". Radiocarbon 51(1): 337-360.

Cardoso, J. L. 1997/1998: “A ocupação campaniforme do povoado pré-histórico de Leceia”. Estudos Arqueológicos de Oeiras 7: 89-153.

Cardoso, J. L. 1999/2000: "Aspectos do povoamento da Baixa Estremadura no decurso da Idade do Bronze". Estudos Arqueológicos de Oeiras 8: 355413.

Cardoso, J. L. 2000a: "The fortified site of Leceia (Oeiras) in the context of the Chalcolithic in Portuguese Estremadura". Oxford Journal of Archaeology 19 (1): 37-55.

Cardoso, J. L. 2000b: “O 'fenómeno' campaniforme na Estremadura portuguesa”. Actas do III Congresso de Arqueologia Peninsular (Vila Real 1999) 4: 353-380. Porto.

Cardoso, J. L. 2001: "Le phénomène campaniforme dans les basses vallées du Tage et du Sado (Portugal)". In F. Nicolis (ed.): Bell Beakers Today. Proceedings of the International Colloquium, Riva del Garda (Trento 1998): 139-154. Trento

Cardoso, J. L. 2004: "An interpretation of the Bell Beaker cultural sequence in the Tagus stuary region: data from Leceia (Oeiras)". Journal of Iberian Archaeology 6: 147-156.

Cardoso, J. L. 2005: “As cerâmicas campaniformes do povodo pré-histórico de Leceia (Oeiras). Uma proposta de interpretação do fenómeno campaniforme na região do estuário do Tejo". In D. Carvalho; D. Vila Maior and R. A. Teixeira (eds.): $\operatorname{Des}(a)$ fiando discursos. Homenagem à Prof. Doutora Maria Emília Ricardo Marques. Universidade Aberta. Lisboa: 151-157.
Cardoso, J. L. 2007: “As cerâmicas decoradas précampaniformes do povoado pré-histórico de Leceia: suas características e distribuição estratigráfica". Estudos Arqueológicos de Oeiras 14: 9-276.

Cardoso, J. L. 2008: "The chalcolithic fortified site of Leceia (Oeiras, Portugal)". Verdolay 11: 49-66.

Cardoso, J. L. 2010: "O povoado calcolítico fortificado do Outeiro Redondo (Sesimbra). Resultados das escavações efectuadas em 2005". In V. S. Gonçalves and A. C. Sousa (eds.): Transformação e mudança no centro e sul de Portugal: o 4. ${ }^{\circ}$ e o 3. ${ }^{\circ}$ milénios a.n.e. (Cascais 2005): 97-129. Cascais.

Cardoso, J. L. 2010/2011a: "Ocupação campaniforme de Leião (Oeiras)". Estudos Arqueológicos de Oeiras 18: 9-32.

Cardoso, J. L. 2010/2011b: “O povoado calcolítico da Penha Verde (Sintra)". Estudos Arqueológicos de Oeiras 18: 467-552.

Cardoso, J. L. 2010/2011c: “O casal agrícola do Bronze Final de Abrunheiro (Oeiras)". Estudos Arqueológicos de Oeiras 18: 33-74.

Cardoso, J. L. and Caninas, J. C. 2010: "Moita da Ladra (Vila Franca de Xira). Resultados preliminares da escavação integral de um povoado calcolítico muralhado". In V. S. Gonçalves and A. C. Sousa (eds.): Transformação e mudança no centro e sul de Portugal: o 4. ${ }^{\circ}$ e o $3 .^{\circ}$ milénios a.n.e. (Cascais 2005): 65-95. Cascais.

Cardoso, J. L. and Soares, A. M. Monge 1990/1992: "Cronologia absoluta para o campaniforme da Estremadura e do Sudoeste de Portugal". O Arqueólogo Português Série IV, 8/10: 203-228.

Cardoso, J. L. and Soares, A. M. Monge 1996: "Chronologie absolue pour le Néolithique et le Chalcolithique de l'Estremadura portugaise - la contribution de Leceia". L'archéométrie dans les pays européens de langue latine et l'implication de l'archéométrie dans les grands travaux de sauvetage archéologique. Actes du Colloque d'Archéométrie 1995, Perigeux. Révue d'Archéométrie supplément 16: 45-50.

Cardoso, J. L.; Norton, J. and Carreira, J. R. 1996: "Ocupação calcolítica do Monte do Castelo (Leceia, Oeiras)". Estudos Arqueológicos de Oeiras 6: 287-299.

Cardoso, J. L.; Soares, A. M. Monge and Martins, J. M. M. 2010/2011: "Fases de ocupação e cronologia absoluta da fortificação calcolítica do Outeiro Redondo (Sesimbra)". Estudos Arqueológicos de Oeiras 18: 553-578.

Cruz, D. J. da 1992: A mamoa 1 de Chã de Carvalhal (serra da Aboboreira). Conímbriga/Anexos 1, Instituto de Arqueologia da Faculdade de Letras de Coimbra. Coimbra.

Ferreira, O. da Veiga and Silva, C. Tavares da 1970: "A estratigrafia do povoado pré-histórico da Rotura (Setúbal): nota preliminar". I Jornadas Arqueoló-

Trab. prehist., 71 N N. $^{\circ} 1$, enero-junio 2014, pp. 56-75, ISSN: 0082-5638

doi: $10.3989 /$ tp. 2014.12124 
gicas da Associação dos Arqueólogos Portugueses (Lisboa 1969) 2: 203-225. Lisboa.

Gonçalves, V. S. 1971: O castro da Rotura e o vaso campaniforme. Junta Distrital de Setúbal. Setúbal.

Harrison, R. J. and Mederos Martín, A. 2001: "Bell Beakers and social complexity in Central Spain". In F. Nicolis (ed.): Bell Beakers Today. Proceedings of the International Colloquium, Riva del Garda (Trento 1998): 111-124. Trento.

Harrison, R. J. 1977: The Bell Beaker cultures of Spain and Portugal. American Museum of Prehistoric Research, Peabody Museum, Harvard University. Cambridge, Mass.

Kunst, M. 1987: Zambujal. Glockenbecher und Kerbblattverzierte Keramik aus den Grabungen 1964 bis 1973. Madrider Beiträge 5, 2. Verlag Philipp von Zabern. Mainz am Rhein.

Kunst, M. 1996: “As cerâmicas decoradas do Zambujal e o faseamento do Calcolítico da Estremadura portuguesa". Estudos Arqueológicos de Oeiras 6: 257-286.

Kunst, M. 2010: "Zambujal. A dinâmica da sequência construtiva". In V. S. Gonçalves and A. C. Sousa (eds.): Transformação e mudança no centro e sul de Portugal: o $4 .^{\circ}$ e o $3 .^{\circ}$ milénios a.n.e. (Cascais, 2005): 131-153. Cascais.

Kunst, M. and Lütz, N. 2008: "Zambujal (Torres Vedras, Portugal). Zur Prazision der absoluten Chronologie durch Untersuchungen na der vierten Befestigungslinie". Madrider Mitteilungen 49: 29-63.

Kunst, M. and Lütz, N. 2010/2011: "Zambujal (Torres Vedras), investigações até 2007. Parte 1: sobre a precisão da cronologia absoluta decorrente das investigações na quarta linha da fortificação". Estudos Arqueológicos de Oeiras 18: 419-466.

Leitão, M.; North, C. T.; Norton, J.; Ferreira, O. da Veiga and Zbyszewski, G. 1984: "The prehistoric cave at Verdelha dos Ruivos (Vialonga), Portugal". In J. Guilaine (ed.): L'Age du Cuivre européen. Civilisations à vases campaniformes. Centre Nationale de la Recherche Scientifique. Paris: 221-239.

Reimer, P.; Baillie, M. G. L.; Bard, E.; Bayliss, A.; Beck, J. W.; Blackwell, P. E.; Bronk Ramsey, C.;
Buck, C. E.; Burr, G.; Edwards, R. L.; Friedrich, M.; Grootes, P. M.; Guilderson, T. P.; Hajdas, I.; Heaton, T. J.; Hogg, A. G.; Hughen, K. A.; Kaiser, K.; Kromer, B.; McCormac, F. G.; Manning, S.; Reimer, R. W.; Richards, D. A.; Southon, J. R.; Talamo, S.; Turner, C. S. M.; van der Plicht, J. y Weyhenmeyer, C. E. 2009: "IntCal09 and Marine09 radiocarbon age calibration curves, 0-50.000 years cal BP'. Radiocarbon 51 (4): 1111-1150.

Sanches, M. J. 1997: Pré-História recente de Trásos-Montes e Alto Douro. Sociedade Portuguesa de Antropologia e Etnologia. Porto.

Sanches, M. J. 2008: O Crasto de Palheiros. MurçaPortugal. Câmara Municipal de Murça. Braga.

Silva, C. Tavares da 1971: “O povoado pré-histórico da Rotura: notas sobre a cerâmica". II Congresso Nacional de Arqueologia (Coimbra 1970): 175192. Coimbra.

Soares, J. and Silva, C. Tavares da 1974/1977: “O Grupo de Palmela no quadro da cerâmica campaniforme em Portugal". O Arqueólogo Português, Série III, 7/9: 101-112.

Sousa, A. C. F. A. Bravo de 2010: O Penedo de Lexim e a sequência do Neolítico Final e Calcolítico da Península de Lisboa. Tese de doutoramento em História, Especialidade em Pré-História. Lisboa. Faculdade de Letras da Universidade de Lisboa. 2 vols. http:hdl.handle.net/10451/3480 (accessed 25IV-2014).

Vaultier, M.; Roche, J. and Ferreira, O. da Veiga 1959: "Novas escavações na gruta da Ponte da Lage". I Congresso Nacional de Arqueologia (Lisboa 1958) 1: 111-116. Lisboa.

Zbyszewski, G. and Ferreira, O. da Veiga 1958: "Estação pré-histórica da Penha Verde (Sintra)". Comunicações dos Serviços Geológicos de Portugal 39: 37-57.

Zbyszewski, G. and Ferreira, O. da Veiga 1959: "Segunda campanha de escavações na Penha Verde (Sintra)". I Congresso Nacional de Arqueologia (Lisboa 1958) 1: 401-406. Lisboa. 